\title{
Earth sciences and global development- an IUGS perspective
}

\author{
Written for the retiring Executive Committee of the \\ International Union of Geological Sciences by the Pres- \\ ident (WSF), and the Chairman of the Advisory Board \\ on Publications (WGEC), this article is endorsed by the \\ following members of that Executive Committee: \\ A C Boriani (Vice-President), Italy \\ $R$ Brett (Secretary General), United States \\ U G Cordani (Past-President), Brazil \\ Liu Dun-yi (Vice-President), China \\ F Herve (Vice-President), Chile \\ $G$ O Kesse (Vice-President,), Ghana \\ J F Lovering (Vice-President), Australia \\ N Petit-Maire (Vice-President), France \\ M Schmidt-Thomé (Treasurer), Germany \\ $S$ Uyeda (Vice-President), Japan \\ $\checkmark$ Zharikov (Vice-President), Russia \\ IUGS, a member of the International Council of \\ Scientific Unions (ICSU), is one of the largest non- \\ governmental scientific organisations in the world.
}

'Earth Sciences: job prospects on shaky ground', asserts Holden in Science (1994). 'Geological programmes come under threat', states Macllwain in Noture (1994). 'Geology is under attack', warns Rossbacher in Geotimes (1995). Such disheartening statements are commonplace these days and by no means confined to captions in topical scientific magazines. In many developed and developing countries, the future of the earth sciences and their role in society has been, and continues to be, discussed in academe, government, industry, and relevant scientific councils and societies. Discussion now needs to be translated into international action. so that the enormous and essential contribution that the earth sciences must make to future global development may be expanded.

The state of the earth sciences today is paradoxical. In a strict disciplinary sense, little ails them. Emergent from a scientific revolution in the last quarter-century, they are more dynamic, unified. and vibrant than in the past, and never before have their practitioners taken a more holistic approach to planet Earth and the understanding of how it works. In the sense of application in the service of society, however, the earth sciences are ailing under the recent impact of two contemporaneous, if distinct, aspects of change in the global environment, one demographic and economic, the other biological, physical, and sociological.

Regarding the first of these, geology and related disciplines traditionally have been applied in the exploration for, and exploitation of, natural resources preserved in the Earth's crust-coal, hydrocarbons, and base and precious metals, for the most part. These resources, long indispensable to the economic welfare of the developed nations, were demanded in vast quantities at the beginning of the second half of this century to rebuild (and technologically reshape) a world shattered by two great wars. More recently, other factors have come to influence the global economic role of these natural resources, and the pattern of demand and supply has changed. Population growth in the developed countries has fallen to low lev- els or become static, and these countries now make more efficient use of many of the resources they exploit. In contrast, population growth in most developing countries continues to climb (in some at an alarming rate). According to the World Resources Institute, $83 \%$ of the global population will live in what are now developing countries by 2025 . Thus, as the peoples of these countries legitimately strive to improve the quality of life, their increasing demand for raw materials, already evidently on the rise. will continue. Concurrently, recent emphasis in the industrialised nations on information as a resource has given the high-technology information-based industries an expanding role in the new global economy; and this could be said, too, of the environmental and the manufacturing industries. In these economic considerations, the old and new are inter-related to some extent: a number of new high-technology developments, for example, have been generated by demand from the hydrocarbon and minerals industries; and a central concern of the environmental industries is sustainable development of intra-crustal natural resources. The environmental and geotechnical industries require the services of earth scientists educated and trained more broadly than the geologists and geophysicists traditionally prepared for careers in the natural-resource industries. Those who educate and train the next generation of earth scientists have given insufficient attention to these demographic and economic considerations. At present, therefore, in many industrialised nations. a reduction in employment opportunities for conventionally trained geologists and geophysicists has been complemented by a reduction in undergraduate enrolment in university earth-science departments.

With respect to the second aspect of change, uncertainty prevails within the earth-science community at large as to the degree to which (and the speed with which) the carth sciences can respond to the twin challenges of global change-i.e., exploding human population and deterioration of planet's natural environment. Both have huge implications for the earth sciences, evidenced by increasing demands for larger banks of more refined data on many aspects of the surface and near-surface of the Earth and for new interpretations of the modus operandi of the natural systems prevailing at these levels.

Although, in retrospect, warning signs of the different changes in the global environment may have been too long discounted or ignored, many earth scientists perceive them to have been thrust upon their disciplines with bewildering suddenness. In evolutionary analogy. the rates of environmental change have outpaced the rate of scientific change, generating new strong selection pressures on the earth sciences to which they must respond if they are soon to flourish again as the broad, intensely practical, applied disciplines that they are. Nonetheless, doubt about the actual and potential magnitude and urgency of the adaptive response required continues to restrain reaction, nationally and internationally, and the disciplinary malaise is perpetuated. Meanwhile, in many countries, governmental officials become impatient and call, if not for the elimination and redistribution, then for the restructuring, of earth-science agencies to achieve greater relevance to the new interests and needs of society. Many who make these calls, alas, do so woefully unaware of the contributions the earth sciences have made, or the magnitude and scope of those they must make, in the interests of human welfare and planetary well-being.

At the present rate of increase, Earth's human population, currently about 5.7 billion, will double by $2(38$, and all these people will be dependent for life-support on the natural systems that operate 
in the 'skin' of the Earth. If these people are to maintain a reasonable quality of life, they will require energy, food, water, and materials. all of which carry earth-science connotations in terms of process and space. Among the present global populace, every man, woman, and child who enjoys a high standard of living is responsible for the manipulation and use of about 20 tonnes of rock and associated earth materials per year to meet this range of needs. The volumetric implication lor a future populace of 10 billion, living well, is the manipulation and use of $100 \mathrm{~km}^{3}$ of rock and associated earth materials per year, which would exceed the volume currently moved by all natural processes, including erosion and volcanism, in the same period. Already, too, there is litule high-quality land left empty on the planet. Such considerations bring sharply into focus the fundamental question: what are the chances in the future of preserving the crust of the Farth in anything like its present state?

'Energy, food, water, and materials' may be distinctly different requirements but, in a context of the earth systems that directly or indirectly control their generation, they are as inter-related as their natural production lines. A few examples make the point. Just as all people who live well consume huge amounts of the Earth's raw materials, so they use (and waste) vast quantitics of energy. More than $90 \%$ of that energy is produced by the combustion of fossil carbon in coal, oil, and natural gats-non-renewable resources with finite reserves, discovered by earth scientists. Coal is the least expensive and most plentiful energy source, heavily relied upon by such populous nations as China and India. But continued dependence on coal will exacerbate the high price already paid for its exploitation in terms not only of visible urban pollution of the atmosphere but also of the less visible, yet fundamental and more significant, alleration of the Earth's entire atmospheric shell. Slowly evidence is emerging to show that the by-products of combustion are affecting the balance of radiation between Sun and Earth and the very photosynthetic process upon which humankind depends for the production of food and libre. If as yet uncertain in delail. the consequenecs are potentially catastrophic.

Nor is the damming ol great rivers to generate hydroclectric power a leasible solution to the energy needs of close to six billion people, far less twice that number; and again, such forms of anthropogenic interterence are now recognised to have a profound effect on various natural systems. Run-olif from the continents is one of the great, natural, soil-cleaning processes, particularly with regard to salts. Modifying a river's discharee into the ocean can alter the marine energy-transport system, or perturb the marine biomass by changing the nutrient flux. Yet round the world, the damming of mighty rivers continues, prompting the question: will any major river on the planet flow naturally to the sea by the year 2100 ? Earth scientists must attempl to unravel the polential consequences of human intervention to such an extent, and do so in terms of future, regional, energy-. food-, and water-supplies. Indeed, they must face the prospect of climatic and ecosystemic instability on a global scale resulting from the artificial damming of all, or even many, of the great rivers of the world. Compelling evidence for such comes from the recent geological history of North America, when meltwaters from the retreating continental ice-sheet, released at a rate comparable to that of tresh water from the Amaron River today, were naturally diverted to the North Alantic (ocean by way of the St Lawrence River rather than being allowed to flow to the Gulf of Mexico by way of the Mississippi River. This diversion is held to have triggered the events that induced the 1000 -year cold spell of the little lee Age (Younger Dryas), about 11000 years ago.

Critical water-supply problems now exist in over 40 of the world's nations. In some with arid and semi-arid lands, the problem might be alleviated by the discovery and measured exploitation of porous sedimentary groundwater reservoirs (acuifers), whereas in others, the problem derives from gross misuse of such reservoirs through essentially unplanned mining of the waters for agricultural and industrial uses. Benefits from such misuse, such as diversifjed and enhanced crop production, will be short-term: climatic and geological controls on many large aquifers dictate that, in terms of the time needed for their natural regeneration, their waters should have been treated as non-renewable resources. New aquifers must he sought and, with existing ones, used in a sustainable fashion. Such development demands the expertise of earth scientists thoroughly knowledgable about the geology of the reservoirs and capable of calculating all factors that may influence their draw-down and resupply.

Pcople who live well produce vast amounts of waste-about one tonne per person per year in North America. If, in the future, 10 billion people were to do the same, the planetary surface would have to absorb $10 \mathrm{~km}^{3}$ of complex wastes aach year, ranging from coal ash to plutonium and raw sewage to household garbage; and to these must now be added gaseous phases, like carbon dioxide. Already, cities have become the foci of both atmospheric pollution and ground pollution. Earth scientists must devise new, safe, disposal sites for all kinds of waste, irreducible by recycling. which guarantee the integrity of peripheral food-generating soils and water supplies. In the next decalde or two, tens of billions of dollars will be spent worldwide on the disposal of radioactive wastes. Where are the best sites? Serious mistakes in selecting these would be intolerable. and the key evidence will come from geology. And what of the new gaseous wastes - carbon dioxide and other "greenhouse' gases? Might they be disposed of in crustal rocks?

If, in their wide range of potential applications, the evolving earth sciences are to meet the challenge of the next century, then they must adapt quickly to the selection pressures being exerted upon them by relevant aspects of the prevailing global enviromment. What is relevant has long transcended the widely recognised "climatic warming' and 'sea-level rise' of conventional "global change" as it has also other aspects of the global environment that still tend to be perceived and precribed too narrowly in terms of the conventional natural-science disciplines and their engineering applications. As this article purports to show, the relevant aspects now extend to demographic, economic, political, and sociological considerations. Moreover, the prevailing global environment continues to be (and for some time likely will remain) in a dynamic state. Hence, the adaptive response of the earth sciences needs a built-in plasticity to enable them to meet the challenges of environmental inconstancy in more opportunistic fashion than in the past. The alternative to adaptation is to condemn the earth sciences to survival as a group of increasingly theoretical disciplines whose applications are basically controlled by the economic fortunes of those industries reliant on the traditional intra-crustal resources (long important as these will remain): to endangering the responsible and sustainable development of an increasingly overpopulated and environmentally stressed world in the centuries ahead by failing to supply critical, reliable information. which cannot readily be obtained elsewhere: and, in that connection, to foregoing claim to a central niche among the natural sciences of the future that the earth sciences rightfully should occupy.

The adaplive response must begin with education-the general education of the public and the specialised education of professional earth scientists. Students in training must be exposed to a broader and more general carth-science education than the traditional programs in geology and geophysics have permitted hitherto, yet with out foregoing appropriate consideration of new developments in these core disciplines. The emphasis must be on earth systems, i.e., on the interactive processes that determine how the Earth works, and this will require exposure not only to the basic sciences, mathematics, and the traditional subdisciplines of geology, but also to atmospheric science, earth and solar-terrestrial physics, ecology and other aspects of biology, oceanography, and computer science. The standard four-year, university-degree program that has found favour in many countries may have to be replaced by a preliminary generalscience qualification and an ensuing professional earth-science degree, following the pattern for law and medicine in many universities. Academic institutions must also be prepared to offer short course instruction in earth-system science to established professional practitioners. None of this, too, can be at the expense of basic research in the earth sciences. Many outstanding, recent, scientifictechnological (and economic) advances have come from new under 
standing of basic systems. Thus, the gloomy predictions of the Club of Rome (Limits to growth, 1972) on the future of non-renewable resources were published just as new understanding of the convection system of the Earth (plate tectonics) was developing from studies of the ocean floors-studies that were to change totally quantification of the planetary resource base.

The public at large must be brought to appreciate that the Earth never has been or will be stable, because the interactive natural systems that operate on and within it constantly seek but never attain a state of equilibrium. That same public must be made to recognise that their natural life-support systems (and those of all other creatures with whom they share their planetary environment) are the surficial soil-water system, and the related systems operating at shallow crustal depths. And that same public must be given some understanding of what can be learned about the future from the geological past-about what in terms of materials, processes, and time underlie the seemingly unchanging outer shells of the Earth; about biological and physical fluctuations, their causes and predictability; and about the dramatic (commonly disastrous) short-term events of earth history. The message is clear, if staggering in its implications: regardless of the exponential rise in human population predicted for the next century, the global public must increasingly become responsible managers of their planetary home. Earth scientists and other scientists cannot alone preserve and restore Earth's natural environment; the co-operation and support of a better-educated world citizenry is mandatory.

Governmental and industrial earth scientists have key roles to fill. Geological surveys (national, provincial, state) must become the principal collectors, processors, and storers of data about the portions of the Earth falling within their jurisdictions. To the fullest extent possible, these organisations should collaborate and co-operate with one another and with other earth-science agencies and institutions on an international basis. Geological surveys must produce new, precise maps, at appropriate scales, summarising analyses and interpretations of all basic kinds of data required for virtually every form of land use. For these new maps, the regional geological and geophysical maps that many surveys already have compiled provide the indispensable base upon which new kinds of data should be superimposed. In countries which lack these regional geological and geophysical base-maps, the task of producing them should be pursued with urgency. Good maps, as a component of the total Geographic Information Systems (GIS) data-base, must also be appreciated for what they are; many are essentially research papers in graphical form, which cannot be produced mechanically and photographically by employing remote-sensing techniques, enormously valuable in many respects as these may be. Governmental earth scientists are also best suited to work on the causes and improve the predictability of natural disasters (earthquakes, floods, landslides, volcanic eruptions).

Industrially based practitioners of the earth sciences, supported by others, must promote greater reliance on less-conventional and new forms of energy (for example, geothermal, solar, perhaps new types of nuclear) and on environmentally benign extractive techniques for all kinds of material resources (mining by deep bacterial leaching, for example). These actions must be accompanied by enhanced re-use of materials and their sites of concentration-better front-end design for quality control and recycling, and end-use design (of mines, for example) for waste disposal or water storage. Future requirements will demand that only the most effective and environmentally safe extractive systems be applied to the most concentrated deposits in the most efficacious geological settings, and planning for this must be global.

To meet the challenges of next century, IUGS continues to seek new approaches to applying the earth-sciences for human welfare and planetary well-being. For example, the Union has sought to strengthen its involvement in the International Decade of Natural Hazard Reduction, secured enhanced funding for the redefined objectives of its successful International Geological Correlation Project, jointly sponsored with UNESCO, and sought to initiate and maintain a strong presence in other joint ventures. It has embarked

on a review of its commissions, with the aim of disbanding ones that have reached their goals, redefining the objectives of others, increasing support for still others with particularly relevant and timely missions ('Cogeoenvironment' a case in point), and creating new ones, as necessary. Recently, it has prevailed upon the International Council of Scientific Unions to sponsor a new 'Partnership for Earth Management,' with a view to making available the integrated global expertise needed to assess the impact-environmental, long-term economic, and social - of any proposed major development. The Executive Committee of the Union is now seeking to identify a small number of research thrusts, appropriately broad-based in both subdisciplinary and geographic respects and spanning both the fundamental and applied earth sciences), in which it can invite and support a number of commissions, subcommissions, working groups, and affiliated organisations to work collaboratively in multidisciplinary partnerships. Bearing directly or indirectly on these latest initiatives is the realisation that, increasingly, layman and professional alike must understand better the earth systems that sustain all forms of life on the planet, and the ramifications that emanate from them. Only in this way will Earth's growing human population learn to treat the planet with respect and leave it the better for their presence.

\section{References}

Meadows, D H. Meadows, D, Randers, J, and Bherens, W S, 1972. Limits to growth: A report for the Club of Rome's project on the predicament of mankind: Universe Books, New York, 205 pp.

Macllwain, C, 1994. Geological programmes come under threat: Nature, 372, p. 715 .

Holden, C, 1994. Earth sciences-job prospects on shaky ground. Science, 266, p. 1316.

Rossbacher, L A, 1995. The geologic column: Geotimes, v. 40, no. 4.

$W S$ (Bill) Fyfe, the retiring President of IUGS, is a graduate of the University of Otago. He has been a researcher and teacher at Otago, Berkeley, London, Manchester and Western Ontario where he became Dean of the Faculty of Science. He has been awarded many academic honours in geoscience and has been a visiting lecturer or professor at numerous institutions around the world. His interest in geochemistry. and the applications of geoscience to environmental management, has taken him to developing countries in all parts of the world.

W GE (Glen) Caldwell, a graduate of the University of Glasgow, taught for 30 years in Saskatchewan. Currently, he is Professor of Geology in the University of Western Ontario. He has been President of the Geological Association of Canada, the Canadian Geoscience Council and Vice-president of IUGS. He is Chairman of the Union's Advisory Board on Publications and has been an editor for the Geological Society of America and of the Canadian Journal of Earth Sciences. His principal research interest is in the biostratigraphy of sedimentary basins.
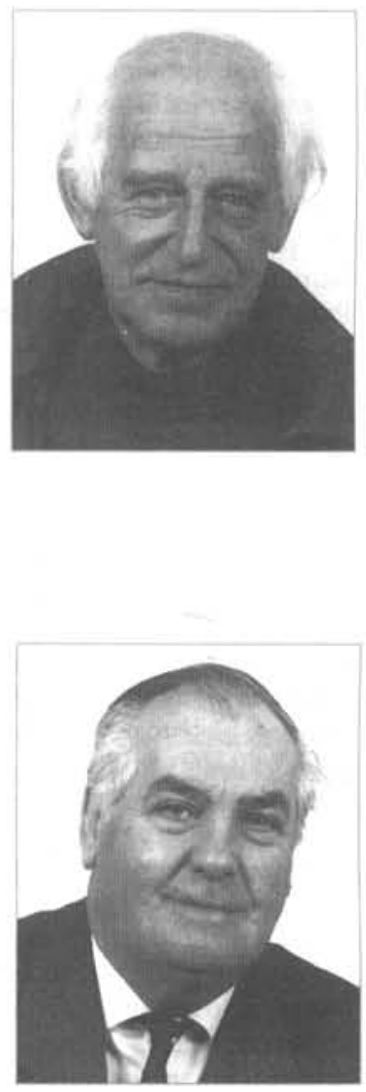